\title{
Human Capital Management and Work Behavior: Evidence from Nepali Life Insurance Companies \\ Prakash Kumar Gautam*
}

\begin{abstract}
Background: Human resource is dynamic and complex ever because of changes in local, regional and global dimensions. Managing people for optimal use of their competencies for organizational purpose has no options. Employee motivation and employee turnover is being the central issue in the modern organizations, corporate movement of competent people is being the regular corporate news in business arena. Human capital management (HCM) helps them to be satisfied and being positive to their work and the organization. It helps organization to cope with turnover challenge and deviant workplace behavior. Employee motivation, satisfaction, job burnout, turnover are being common challenges to the management. To cope with such challenges, organizations should have strategic focus on human capital management.

Objectives: This study aims to explore the situation of human capital management in Nepali insurance companies and the employee's satisfaction from human capital management. The study also aims to examine the association between satisfaction from HCM and workplace behavior. To examine the gender influence on workplace behavior of the employees created by HCM.

Methods: This study was conducted with correlational research design. Primary data for each variable was collected from 402 employees of different seven life insurance companies having at least five years of business experience. To observe the current HCM practices, 3-Point statements were asked. Structured questionnaire with 5-Point Likert Scale was used to collect responses on satisfaction from HCM and the satisfaction towards positive workplace behavior. Descriptive statistics, Pearson correlation, and independent sample t-tests were used to examine the objectives.
\end{abstract}

Result: Results of the study revealed that Nepali insurance companies have maintained human capital management causing employee satisfaction. Employees have reported that they have positive workplace behavior. Female employees have more positive workplace behavior of employees. Employee's satisfaction from HCM is obtained having positive relationship with workplace behavior.

Conclusion: Nepali insurance companies have satisfactory HCM effective to motivate their employees. Employee's satisfaction leads for positive workplace behavior. There is no gender difference in satisfaction on HCM while female have more positive workplace behavior in comparison to their male counterparts.

Implications: To cope with intense competition among the competitors in Nepali insurance industry, this study provides strong evidence to focus on HCM and positive workplace behavior.

Key words: Human capital management (HCM), HR competencies, HR practices, $H R$ system, HR deliverables, workplace behavior.

${ }^{\star}$ M.phil., Lecturer, Faculty of Management Tribhuvan University

Email: gdpconsultingnepal@gmail.com,pkg@shankerdevcampus.edu.np 


\section{Background}

Business environment is ever changing and the only constant thing in the world is change (Elving, 2006). Business organizations are not only facing change in products i.e. goods or services but also the way of serving the goods and services. Product development and innovation is the ever growing challenge to the organizations in terms of designing, producing and delivering the goods and services. Adapting new technology could help to cope with changing needs to increase competency of the organization which is possible only through effective use of human capital available in the organization. Human Capital (HC) is the sum total of knowledge, skills, experience and other relevant workforce attributes residing in people of an organization responsible for efficiency, effectiveness and productivity. Planning and implementation of human resource management functions i.e. acquisition, development, utilization and maintenance of human talents in the organization to fit to the job requirement is the human capital management. Human Capital Management (HCM) is an approach for effective and efficient planning, acquiring, utilizing and maintaining the human competencies of people required for organization. Human capital is one of the major source dynamic competitive advantages of the organization. Effective HCM aims at getting skilled, dedicated and positive people for the right job, enhancing their skills to cope with increasing skills need, motivating them to devote their optimal efforts at organizational purpose and maintaining the competent people with succession planning. Competency of the organization in HCM brings the differences in organizational efficiency which ensures the higher effectiveness and performance. Effective HCM in organizations have proved them as the business icons in competitive world. For this, human resource management should have strategic focus on acquiring and utilization of the champions from the market, or at least need to develop champions through training and development.

With time, approach of undertaking the employees in modern organizations have been changed from liability to asset. This means that the organizations are not accepting the employees as source of competitive advantages. Organizational stability and growth are the output of HCM in today's competitive world. To gain sustainable growth on business, customer satisfaction is inevitable which is, by various research studies have proved that, the consequences of employee's work attitude. HCM is the immediate and both tangible as well as intangible practices of organization causing immediate as well as long term influences on their behavior. Their satisfaction and commitment towards their jobs and organization largely affect on employee satisfaction. Employee's satisfaction ultimately determines the organization's effectiveness. This proves the increasing role of HCM for examining the affective components of the employees.

Insurance business in Nepal is ever virgin area as only 20 percent people in Nepal has the excess to insurance (Economic Survey, 2018/19). Contribution of insurance in Gross 
Domestic Production is 2.6 during the period. These indicators show the immense opportunities to the limited number of insurance companies in Nepal. With more complex business situation, increasing health risk, and complexities in the life increase the business opportunities to the insurance companies. But, growth in business insurance is in arithmetic progression. This situation has created opportunity to the insurance business but increasing number of insurance companies and their products, there is high competition among them. With increasing competition, changing socio-cultural dimension, changing in life style and widening safety awareness, insurance companies are enjoying both opportunities as well as the challenges. Selling insurance products i.e. policies is not easy task as these products are unsought products. It is already late to spread the information regarding the short-term and long-term benefits of the insurance in comparison to investment. Nepal government has introduced several insurance benefit packages like health insurance, agriculture insurance, cattle insurance, etc. but many prospects customers have not sufficient information regarding insurance benefits, provision and the other facilities tied with insurance policies. Though employees of the insurance companies cannot sell their products directly, but their work attitude definitely affect of the satisfaction of both insurance agents as well as the customers. Employee's role becomes stronger in spreading individual society members along with facilitating them from their offices. This situation forced to pick up the human capital management as strategic tool to increase the organizational efficiency. It is proved that only satisfied employees can deliver their fullest potential to satisfy their customers and even contribute to develop promotional plans, policies and strategies. HCM is expected to lead the organization in competitive environment. This research aims to explore the human capital management initiations in Nepali Insurance Companies and to examine the role of HCM in employee's affective component in corresponding companies.

\section{Review of Literature and Theoretical Framework}

For true and sustainable competitive advantages of the firm, Bontis et al. (2000) suggests that intellectual capital as critical source. Human capital, relational capital and structure capital are the most important dimensions of intellectual capital among which human capital observed to be most dominating influence in employee effectiveness and business efficiency. Isaac (2004) reported that intellectual capital directly influences on wealth generation of the organization. Intellectual capital not only satisfies that consumers, it increases the employee workplace attitude and organizational commitment. It has most significantly contributes for improving competitive position of any firm (Marr, 2004). Reed et al. (2006) theoretically linked the intellectual capital with firm's competitive advantages. To effectively implement the relational capital as well as structure capital, human capital need to have lead role. Human capital is composed up of aggregate knowledge, skills, abilities and other competencies of employees (Ployhart \& Vandenberg 
2006). At individual level, human capital is defined as a combination of four elements: genetic inheritances, education, experience and attitudes about life and business (Hudson, W., 1993) which differentiate one individual from other in terms of their skills, creativity, self-efficacy and the commitment. Human capital in modern terms can be explained in terms of described human capital with a macroeconomic perspective, as the driver of national economic activity, competitiveness and prosperity (OECD, 1996).

Barney (1991) suggested that employees are the source of sustainable competitive advantage as it comprises of Valuable, Rare, Inimitable, and Non-substitutable (VRIN). No doubt, globalization has extended the business opportunities along with threats. Productivity, efficiency and effectiveness of any firm can be limited among the skills and the expertise of employees. Their beliefs, value system, creativity and innovative ideas can change the organizational value system and its innovative sphere. Realizing the value of human capital, Bose and Oh (2004) reported that there is a need for firms to control and nurture their human capital to cope with the rapid growth of global competition. Stewart (2007) examined the relationship between intellectual capital and financial performance indicators i.e. earnings per share, return on equity and return annually in the Singapore Exchange based companies and found positive relationship. Peltoniemi and Vuori (2005) reported that elements of intellectual components have always seen as a positive factor, reflecting that more is better than less, and means that the enterprise should maintain it as the source of long-term business success. Companies with greater use of human capital were found with relatively higher stock price (Change, 2007). Hematfar et al. (2013) have concluded that companies can create value and sustain competitive advantages to scale up the corporate success within emerging new challenges.

The RBV believes on competencies, governed through unique resources which serve to enhance organizational productivity. Core competencies are the areas of competitive proficiency and excellence that are not relinquished by emerging competition and that distinguish the organization strategically from its competitors (Leonard-Barton, 1992). Organizations can generate its core competencies through effective HCM (Carmeli \& Schaubroeck, 2005).

Human capital is source of competitive advantage of any organization. It is the core but most dynamic resource of any organization. Thus, resource based view is the widely incorporated focus for the organizational benefits. RBV is used as a basis for analyzing the effects of resources on organizational performance. RBV is a theory about the management of organizational resources like assets, capabilities and competitive advantage to attain predetermined goals. Assets are the possessions of any organization which may be tangible or intangible which are to create and offer products or services; capabilities are processes for using the assets to add value to the products and services (Sanchez, Heena, \& Thomas, 1996), or groups of assets and processes (Fraiha, 2011). 
All firms have assets and capabilities but to what extent they are being used determines the competitive strengths of the firm in the market. Competitive advantage results when the customers of a firm perceive more value in that firm's products and services than the competitor's (Hall, 1993). In this regard, RBV emphasizes on the heterogeneity of resources between companies, and how long this heterogeneity can exist. This means that, RBV explains the use of specific resources and the sustainability of that specificity on resource for the long term competitive advantages. In this sense, the human capital is more dynamic, rare, low imitable, low substitutability. HCM is thus, driven by the RBV approach of creating sustainability of organizational growth.

Human capital is composed of different factors like HR competencies, HR practices, HR system and HR deliverables. HR competencies include administrative expertise, employee expertise, strategy implementation and change agency; HR practices incorporates all the organizational efforts of getting best people for the right job which includes recruitment and selection, job design, training and development, performance management and reward management. HR system is composed with the flow of HR inputs into organizational outputs. HR system includes variables like HR alignment, integration and differentiation. Likewise, HR deliverables is composed with the mindset of workforce, technical skills and knowledge and the workforce behavior.

Based on RBV approach, the dimensions of human capital are finalized adopting the model suggested by Beatty et al. (2003) with slight modification. These dimensions are developed to measure the human capital management of the organizations. HR competencies are the set of observable and measurable knowledge, skills, abilities and personal attributes which contribute to enhance the performance of employees as well as organization. Accountability, adaptability, communication, customer focus, quality focus, leadership ability, etc. are the major components of HR competencies. HR practices are, in general, are the common human resource management functions. Recruitment \& selection, HR planning, training \& development, performance and reward management, maintaining employee relations, etc. are HR practices in the organization. HR system is comprised with alignment, integration and differentiation.

Becker and Huselid (2006) argued that appropriately configured and directed human resource management (HRM) becomes effective in encouraging higher job performance and provides evidence of positive work behavior i.e. wider 'extra-role' to the organization. This proves that HCM helps to develop the positive employee attitude towards the job and organization. By influencing employee's attitude positively to the job and organization, organizations gain higher performance (White \& Bryson, 2013). They provided a strong evidence of non-linear relationship between employee job attitudes and HRM in a positive quadratic term stating that employee attitudes rise more steeply with higher levels of HRM. Gagné and Deci (2005) reported that employees who are autonomously motivated 
at work feel their jobs more interesting and take jobs personally important because of which job performance gets increased. This proves that human resource management is positively associated with higher level of employee satisfaction and formation of positive job attitudes which ultimately leads higher performance at individual as well in organizational level. HCM thus, affects on organizational outcomes i.e. task performance, contextual performance, lateness, absence and turnover. Several researchers have reported positive association between overall job attitude and engagement.

Based on various literatures, it is clear that the HRM systems, synonymously HCM can enhances the organizational values i.e. helps to make people positive. HCM as a component of HRM system satisfies the employees developing positive attitude for which it is essential to communicate that the HCM system cares ideas, views and dignity of the employees to build up their individual as well as collective identity. Realization of complementarity of internal and external rewards through best practices of HCM with full of commitment consistently from the organization, employees foster positive job attitudes towards job and the organization. The intensity of the positive attitudes depends on intensive HRM system implemented in the organization. When the employees have positive attitude, they perform favorable perceptions of workplace practices and tend to perform relatively high level of job satisfaction, commitment and other attitudes (Gong et al. 2009; Nishii et al. 2008; Takeuchi et al. 2007; 2009). Yu and Egri (2005) also revealed the significant impact of HR practices on employee's affective commitment on Chinese firms. Senyucels (2012) proposes that the HRM is a combination of people centered management practices i.e. HCM which anticipates the employees as assets to creating and maintaining skillful and committed workforce for achieving organizational goals. As a component of HCM, better job assignment, employees possess greater commitment, leading to better job performance (Klaus, LeRouge \& Blanton, 2003).

Job satisfaction is the extent of positive feeling of fulfillment of expectations from the job. Higher job satisfaction indicates the extent of employees' positive feeling while low job satisfaction describes the negative feelings of employees towards their jobs and organizational. Job satisfaction is the describing variable for work behavior of the employees. Simply, it is proved that higher the job satisfaction, more positive work behaviors are expected to perform by the employees. Job satisfaction and the workplace deviant behavior have negative relation (Omar, Halim, Zainah, Farhadi, Nasir, and Khairudin, 2011) means that satisfied employees show positive work behavior. Their study also revealed positive relationship of stress with deviant workplace behavior. Job satisfaction, in this sense is most essential to reduce the job stress and negative workplace deviant behavior.

Dessler (1993) suggested the managers that they must build employee commitment i.e. positive work behavior. Through positive work behaviors, employees tend to be self-disciplined and higher level of commitment. They tend to be identifiable through 
involvement in the organizational processes anticipating the organizational values and goals at first priority and exert their best effort on behalf of organization to fulfill the organizational commitments. Satisfied employees show positive work behavior by showing their desire to remain with the organization (Mowday, Porter, \& Steers, 1979).

Human capital management should be aligned with design and strategy, organization's culture, structure, and strategy. Many researchers focused on human resource practices and functions but neglected the human capital management for innovation and development of products from effective involvement of employees. The major concern like whether Nepali insurance companies pays due concern on managing human capital or not. There is noticeable level of job turnover rate in this sector. This might be because of poor attention of organizations to satisfy and retain their human resources. It is to explore the condition whether HR practices, HR competencies, HR system, and HR deliverables are satisfying the employees. It also requires examining the influence of human capital on work behavior of the employees. For examining the work behavior of employees, their behaviors regarding making subtle changes to their work tasks to increase their enjoyment, creating opportunities to connect with more people at work, or simply trying to view their job in a new way to make it more purposeful need to be addressed as Slemp \& Vella-Brodrick (2013). While some jobs will provide more of these opportunities than others, there will be situations in all jobs where one can make subtle changes to make it more engaging and fulfilling.

Though the employees are not involved to search customer from their own; the insurance agents of the respective companies create business for them but they may work on the basis of rate of commission. Insurance agents may not considered as long-term strategic partners of the company though they are considered as the human capital for short term. They need to be properly monitored, managed and facilitated in regular basis by the employees of the respective company. Company gets enough business and gradual improvement in it only through the effective management of human capital involved directly as employees and indirectly as agents. Thus, HCM is the only way for developing employee satisfaction and their positive work behavior so that they not only involve day to day technical job but also to supervise, monitor, and facilitate to the agents. Workforce mindset, technical skills \& knowledge and workforce behavior are the selected components of HR deliverables. Conceptual framework is formulated with the understanding that employees satisfaction from HCM leads positive work behavior as presented in figure 1:

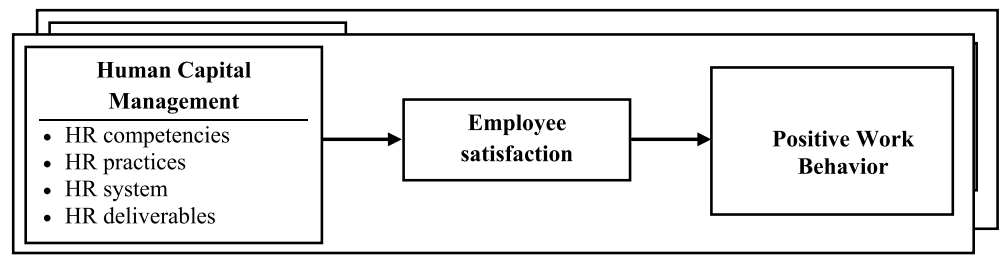

Figure 1: Conceptual Framework 
- Managing HR competencies. Managing the HR professional's special ability in terms of HR expertise, ability to connect HR professionals for the purpose, special business insight, special quality of HR leadership etc. in the organization is the extent of HR competencies management. It is the way to motivate individual HR professional as well as induced satisfaction to the other people working with or under him/her.

- Managing HR practices. Practices regarding HR functions starting with recruitment to selection, socialization, training and development, performance appraisal, compensation and reward management, maintaining workplace relationship, employee retention functions, etc. are the HR practices in the organization. Managing these functions for effectiveness and efficiencies of HR deliverables is considered as managing HR practices.

- Managing HR system. HR system is designed to manage HR processes with the combination of hardware and software resources. It comprises of specific business processes and features such as employee records management, payroll, attendance management, and performance evaluations.

- Managing HR deliverables : HR outcomes are commonly termed as HR deliverables. The change in HR paradigm from common HR functionality of what I do? to What I deliver? To the customers, employees and investors. It covers in four distinct fronts enabling HR to be strategic partner, change agent, employee champion and administrative expert, employee champion. Thus, managing HR deliverables is the approach how HRM opt to attract, develop and motivate people to deliver their competencies for betterment of customers, employees and the investors.

- Employee satisfaction. It is the extent of employee's fulfilment of their expectations from HCM in the organization.

Positive work behavior. It is the extent of employee behavior contributing in the favor of organization's sustainable development, customer's benefits and workplace productivity.

\section{Research design}

This study follows the correlational research design. This study anticipates positive work behavior of employees as the minimum criteria for organizational success as the dependent variable and the satisfaction from Human Capital Management (HCM) as describing variable. Demographic variables were considered as the controlling variables for the relationship between describing and dependent variables. Only seven lifeinsurance companies out of 39 insurance companies in Nepal (18 life, 20 non-life and one re-insurance company as on August, 2018) having at least of five years of experience were considered the study units with the logic behind it was that to establish the HCM, 
or not. 25 statements of Five-Point Likert Scale questionnaire was prepared to measure the employee satisfaction through human capital management in the organization and 15 statements for measuring their work behavior. Croanbach's alpha was used to conclude the reliability of the questionnaire. With summated average, the level of satisfaction and work behavior were examined while to examine the relationship between satisfaction and work behavior, correlation analysis was used. The study assumed to have the positive relationship between satisfaction through HCM and the positive work behavior.

\section{Major findings and discussion}

Among the 40 statements formulated for exploring the HCM dimensions, respondents reported their cent percent positive response on 27 statement representing that their organization maintain good human capital management practices. These statements integrate all the four dimensions i.e. HR competencies, HR practices, HR system and HR deliverables concluding that Nepali insurance companies, in majority maintain good HCM practices in their organization. Respondents have shown mixed response on 13 statements. This could either because of poor communication of the provisions to employees or because of poor perception regarding existing HCM. Among the statements, majority of the respondents (56.9\%) responded either there is no provision of employee's innovative ideas or respondents have no idea. This indicates that the Nepali Life Insurance Companies have lower participations of employees in the decision making. Following the statement, respondents have shown negative response on the statement 'company maintains environment of respecting skills, knowledge and expertise' (44\% 'no'). Likewise, 49 per cent respondents believe that their organization has no unique HR system or they are not sure about it. Though the majority of the respondents responded that their organizations promote innovative ideas from the employees but 26.9 per cent have reported their disagreements on the statement. Greater concern of HCM, transparent performance appraisal system and commitment for qualified employees and providing working procedure are reported disagreements advocating the company's urgent adjustment in existing HCM.

Reliability statistics was examined with Cronbach's Alpha, for satisfaction through HCM practices and the work behavior were observed 0.847 and 0.743 respectively (Table 1 ) indicating sufficient condition for reliability of the questionnaire to test respective variables.

Table 1

Reliability statistics of respondent's satisfaction level towards HCM and Work Behavior

\begin{tabular}{|l|c|c|c|c|}
\hline Variable & Cronbach's Alpha & N. of Items & Item Means & Item Variances \\
\hline Sat_HCM & 0.847 & 25 & 3.921 & 0.424 \\
\hline WB & 0.743 & 15 & 3.928 & 3.928 \\
\hline
\end{tabular}


Average of the satisfaction level from each of the four dimensions HR practices, HR competencies, HR system and HR deliverables and the overall satisfaction on HCM was examined to test the satisfaction level on statements towards HCM (Table 2). Respondents were observed to have maximum satisfaction on HR competencies followed by HR practices, HR deliverables and HR system. Respondents showed their overall satisfaction on the HCM (mean = 3.920 and s. d. 0.32 ) and positive work behavior (mean $=3.930$ and s.d. 0.289). This result revealed that the employees overall satisfaction is more than the average level in all the components of HCM, overall satisfaction through HCM and the higher level of positive work behavior.

Table 2

Descriptive statistics for respondent's satisfaction on HCM

(AS_HRP-Averagesatisfaction ofrespondents on HRpractices, AS_HRC-Averagesatisfaction of respondents on $H R$ competencies, AS_HRS - Average satisfaction of respondents on $H R$ system, AS_HRD - Average satisfaction of respondents on HR deliverables and OAS_HCM Average satisfaction of respondents on HCM of the company)

\begin{tabular}{lccccc}
\hline & $\mathrm{N}$ & Minimum & Maximum & Mean & Std. Deviation \\
\hline AS_HRP & 402 & 3.17 & 4.67 & 3.909 & 0.306 \\
AS_HRC & 402 & 3.00 & 4.50 & 3.914 & 0.324 \\
AS_HRS & 402 & 3.25 & 5.00 & 3.813 & 0.401 \\
AS_HRD & 402 & 3.00 & 4.60 & 3.883 & 0.340 \\
Sat_HCM & 402 & 3.00 & 5.00 & 3.920 & 0.301 \\
Sat_PWB & 402 & 3.00 & 4.00 & 3.930 & 0.289 \\
\hline
\end{tabular}

To observe the correlation between overall satisfaction from HCM and its components, Pearson's correlations were calculated at 0.01 per cent level of significant with two-tailed test (Table 3). From the observation, maximum association of HCM was found with HR competencies (0.884) followed by HR practices (0.846), HR deliverables $(0.840)$ and HR system (0.833). Result revealed the positive significant relationship of overall satisfaction of employees through various dimensions of HCM. This also states that the employees satisfaction lies with competencies management practices of the organization, workplace practices and HR policies. This is also important to maintain the HR deliverables. Results provide evidence of high level of employee satisfaction from managing HR competencies and low association with HR system though the correlation coefficients were not much different. This may be because of poor linkage between the HR system, HR deliverables and the HR practice or sometimes because of cultural chaos. For increasing satisfaction from HR system, it should be simple to understand and use within the scope of transparent and dynamic provisions.

Average of the satisfaction level from each of the four dimensions HR practices, HR competencies, HR system and HR deliverables and the overall satisfaction on HCM was 
examined to test the satisfaction level on statements towards HCM (Table 2). Respondents were observed to have maximum satisfaction on HR competencies followed by HR practices, HR deliverables and HR system. Respondents showed their overall satisfaction on the HCM (mean = 3.920 and s. d. 0.32 ) and positive work behavior (mean $=3.930$ and s.d. 0.289). This result revealed that the employees overall satisfaction is more than the average level in all the components of HCM, overall satisfaction through HCM and the higher level of positive work behavior.

Table 3

Correlation between overall satisfaction between HCM and its components

\begin{tabular}{lccccc}
\hline & AS_HRP & AS_HRC & AS_HRS & AS_HRD & Sat_HCM \\
\hline AS_HRP & 1 & & & & \\
AS_HRC & $.724^{* *}$ & 1 & & & \\
AS_HRS & $.721^{* *}$ & $.437^{* *}$ & 1 & & \\
AS_HRD & $.686^{* *}$ & $.718^{* *}$ & $.643^{* *}$ & 1 & \\
Sa__HCM & $.846^{* *}$ & $.884^{* *}$ & $.833^{* *}$ & $.840^{* *}$ & 1 \\
\hline
\end{tabular}

** Correlation is significant at the 0.01 level (2-tailed).

Table 4 observes the differences in satisfaction level of male and female respondents regarding the overall HCM practices of their organizations. Mean satisfaction level of male respondents is observed to be less than female respondents $(3.91<3.94)$ though the standard deviation of female respondents is high.

Table 4

Group statistics observing mean difference on satisfaction level towards HCM of gender

\begin{tabular}{clcccc}
\hline & Gender & $\mathrm{N}$ & Mean & Std. Deviation & Std. Error Mean \\
\hline \multirow{2}{*}{ Sat_HCM } & Male & 264 & 3.91 & 0.277 & 0.017 \\
& Female & 138 & 3.94 & 0.344 & 0.029 \\
\hline
\end{tabular}

To examine whether the difference is significant or not, independent sample test was conducted (Table 5). Sig. value under Levene's Test for equality of variances for satisfaction from human capital management is less than 0.05 which is sufficient to reject null hypothesis 'there is no significant difference between variance of score'. This means null hypothesis of the assumption of equal variance is rejected and hence $t$-value is observed in the second line i.e. 'equal variance cannot be assumed'.

Table 5

Examining significance of difference in satisfaction of male and female respondents

\begin{tabular}{llccccc}
\hline & \multicolumn{3}{c}{$\begin{array}{c}\text { Levene's Test for Equality } \\
\text { of Variances }\end{array}$} & \multicolumn{2}{c}{ t-test for Equality of Means } \\
\cline { 2 - 6 } & F & Sig. & t & df & Sig. \\
\hline \multirow{2}{*}{ Sat_HCM } & $\begin{array}{l}\text { Equal variances } \\
\text { assumed }\end{array}$ & 6.443 & 0.012 & -0.928 & 400 & 0.354 \\
& $\begin{array}{l}\text { Equal variances not } \\
\text { assumed }\end{array}$ & & & -0.868 & 231.681 & 0.387 \\
\hline
\end{tabular}


Table 5 reveals that, $\mathrm{p}$-value of $\mathrm{F}$ is less than 0.05 , providing sufficient evidence to reject the null hypothesis for equal mean of samples. In this case, to test the significant difference, 'Equal variances not assumed' column is followed for t-test to conclude whether the mean difference is significant or not. Observing the sig. value (0.387) greater than 0.05 , suggest that there is no significant difference between mean satisfaction score in male and female towards HCM practices in their respective organizations.

Main objective of the study was to examine the impact of human capital management in the organization to the workplace behavior of the employees. Table 6 provides the overall mean satisfaction on the statements representing the positive workplace behavior. Table 6 also provides the mean differences between the male and female respondents.

Table 6

Overall mean and mean differences between male and female respondents

\begin{tabular}{llcccc}
\hline & Gender & $\mathrm{N}$ & Mean & Std. Deviation & Overall mean \\
\hline \multirow{2}{*}{ Sat_PWB } & Male & 264 & 3.91 & 0.282 & \multirow{2}{*}{.93} \\
& Female & 138 & 3.97 & 0.297 & \\
\hline
\end{tabular}

The overall mean on the statements representing positive workplace behavior was observed to be 3.93 describes that employees perform positive work behavior as a consequence of satisfaction from HCM of their organization. Mean value of female is greater than the mean value of male respondents representing that female respondents perform more positive behavior than the male. To examine the significance of the gender in positive workplace behavior, Independent Sample Test was conducted presented in table 7.

\section{Table 7}

Testing gender differences in positive workplace behavior

\begin{tabular}{clccccc}
\hline & & \multicolumn{2}{c}{$\begin{array}{c}\text { Levene's Test for } \\
\text { Equality of Variances }\end{array}$} & \multicolumn{2}{c}{ t-test for Equality of Means } \\
\cline { 3 - 7 } Sat_PWB & \multicolumn{1}{c}{$\mathrm{F}$} & $\mathrm{Sig}$. & $\mathrm{t}$ & $\mathrm{df}$ & Sig. \\
\hline & $\begin{array}{l}\text { Equal variances } \\
\text { assumed }\end{array}$ & 0.708 & 0.4 & -2.071 & 400 & 0.039 \\
& $\begin{array}{l}\text { Equal variances } \\
\text { not assumed }\end{array}$ & & & -2.039 & 266.256 & 0.042 \\
\hline
\end{tabular}

Though there is mean value in the positive workplace behavior in between male and female respondents, significance of the difference was tested by using independent sample t-test. From table 7 , sig. value of the satisfaction on positive workplace behavior is $0.4>0.05$ providing the path equal variance not assumed. Sig. value of $\mathrm{t}$-test for equality of means (0.042) less than 0.05 indicates that the mean workplace behavior of female employees is more positive in comparison to the male employees. It is naturally true that female are more passionate and tend to be more loyal and permanent. 
Table 8

Correlations between positive workplace behavior and components of HCM

\begin{tabular}{rrrrrr}
\hline & AS_HRP & AS_HRC & AS_HRS & \multicolumn{1}{c}{ AS_HRD } & Sat_HCM \\
\hline Sat_PWB & $.427^{* *}$ & $.371^{* *}$ & $.271^{* *}$ & $.400^{* *}$ & $.420^{* *}$ \\
\hline
\end{tabular}

${ }^{* *}$ Correlation is significant at the 0.01 level (2-tailed).

Table 8 provides the correlations between positive workplace behavior and the overall satisfaction from HCM. From the result, it is observed that overall satisfaction from HCM leads to positive workplace behavior of the employees. Among the components of HCM, human resource practices have higher significant association with workplace positive work behavior (0.427) followed by human resource deliverables (0.400), HR competencies (0.371) and HR system (0.271).

\section{Conclusion and Implication}

It is the open secret that human resource is the strength as it the only resource to mobilize non-human resources of the organization at the optimal level to satisfy the consumers and attain organizational goals. Human resources is the source of competitive strength of any organization as it provides unique creativity and innovation to lead the competition. For higher effectiveness and efficiency of any organization, it is essential for most optimal use of its human capital available in the organization and even need to work-out to develop competitiveness of the people through enhancement of skills, knowledge and willingness for optimal delivery.

Results in this study revealed that the employees of Nepali insurance industry are satisfied. They reported that insurance companies have good practices in HR competency management, HR policies and practices, HR system and HR deliverables. Employee's satisfaction on human resource competencies as many of the young employees prefer to get acknowledged for their competencies, opportunities of growth of competencies through training and development. Young employees, as many of the insurance companies wish to hire young people to increase can be satisfied and motivated through management of human competencies. As the respondents have shown low satisfaction level in HR system which could be because of lack of organizational communication or lack of proper and long-term vision of HCM.

Regarding the overall satisfaction of employees from overall HCM in insurance companies, HCM has significant positive relationship with its components. Based on the result revealed, overall satisfaction has higher association with human resource competencies management. This implies that employee prefer more for managing their competencies as well as initiating for increasing their competitive strength through policies, training and development, participative decision making process, etc. Result also revealed that there 
is no difference in satisfaction from overall HCM practices of the organization based on gender. This implies that male and female employees have same perception regarding the HCM outputs.

Result revealed that the employees are positive in their workplace behavior. They show their satisfaction to HCM establishing positive relationship between HCM and positive workplace relationship. Interestingly, female employees reported that they are more positive at their workplace in comparison to their male counterparts. This is because of the socio-cultural set up of Nepali society. Female, in general, till now anticipate employment as the supplementary support to their husband or they consider their involvement in employment for their personal ease to personal expenses. They need to bear dual responsibility, comparatively more duties on household activities for taking care to their wards because of which they do not get enough time for their office. This may lead to low job involvement and engagement resulting that they could be satisfied in low return and show organizational commitment for continuity and initiation for fulfilling customer's expectation.

This research also opened new research scope that what different measures need to use to utilize the employee based competencies and the organizational overall competencies. Among the significant variables human resource deliverables are the most powerful variables as they directly link with customers and hence the sales of the firm. To increase the organizational effectiveness and efficiency, management should concentrate on increasing effectiveness of human resource capital management. Employee's positive workplace behavior should be focused to increase employee satisfaction from workplace behavior as well the consumer satisfaction, searching new market, and developing creativity of employees. It is concluded that the HCM satisfies the employees and causes positive workplace behavior of the employees.

\section{References}

Barney, J. (1991). Firm resources and sustained competitive advantage. Journal of Management, 17, 99-120.

Beatty, R.W., Huselid, M.A., \& Schneier, C.E. (2003). New HR metrics: scoring on the business scorecard. Organizational Dynamics, 32 (2), 107-121.

Becker, B.E. \& Huselid, M.A. (1998). High performance work systems and firm performance: A synthesis of research and managerial implications. In Ferris, G.R. (ed.). Research in personnel and human resources management, Vol. 16, Stamford, CT: JAI Press: 53-101. 
Bontis, N., Keow, W.C.C. \& Richardson, S. (2000). Intellectual Capital and Business Performance in Malaysian industries, Conference paper presented at the 7 th Tun abdul Razak international conference, Dec. 1999.

Bose, S. \& Oh, K.B. (2004). Measuring Strategic value-drivers for managing intellectual capital. The learning Organization, 11(4/5), 347-356.

Byremo, C. (2015). Human Resource Management and Organizational Performance: Does HRM lead to improved Organizational performance?. Thesis in Organization, Leadership and Work Department of Sociology and Human Geography Faculty of Social Sciences, University of Oslo.

Carmeli, A., Schauoeck, J. (2005). Leveraging Human Resource Capital with its Competitive Distinctiveness enhances the Performance of Commercial and Public Organizations. Human Resource Management, 44(4), 391-412. DOI: 10.1002/hrm.20081.

Chang, S. L. (2007). Valuing Intellectual Capital and Firms performance modifying valued added intellectual coefficient in Taiwan IT industry, Unpublished PhD Thesis. Agene School of Business University of Golden Gate USA.

Dessler, G. (1993). Winning commitment, New York: McGraw-Hill, Inc.

Economic Survey, Nepal (2018-19). www.mof.gov.np

Elving, W. J. (2006). The role of communication in organisational change. Emerald Insight, 10(2), 129-138. doi: 10.1108/13563280510596943

Fraiha, S. (2011). The Impact of Human Capital and Organizational Characteristics on the Business Value of Information Technology. Electronic Thesis and Dissertation Repository. 321. https://ir.lib.uwo.ca/etd/321.

Gagné, M. \& Deci, E.L. (2005). Self-determination theory and work motivation. Journal of Organizational Behavior, 26(4): 331-62.

Gong, Y., Law, K.S., Chang, S. \& Xin, K.R. (2009. Human resources management and firm performance: The differential role of managerial affective and continuance commitment. Journal of Applied Psychology, 94(1), 263-75.

Hall, R. (1993). A framework linking intangible resources and capabilities to sustainable competitive advantage. Strategic Management Journal, 14(8), 607-618. 
Hematfar, M., Javid, D., Abadi, H.K.G. (2013). Effects of Components of Intellectual Capital on the Financial Performance of the Cement Industry Accepted at Tehran Stock Exchange, with Regression and Neural Network Approach. Journal of Applied Environmental and Biological Sciences. Vol. 3(9), pp. 155-165. available online at : www.textroad.com

Herremans, I.M. \& Isaac R. G. (2004). Leading the strategic development of intellectual capital. The leadership and organization development Journal, 25(2), 142-160.

Hudson, W. (1993). Intellectual Capital : How to build it, enhance it, use it. New York : John Wiley \& Sons.

Klaus, T. L., C. \& Blanton, J. E. (2003). An examination of the relationships between select nature of work characteristics and organizational commitment of IT professionals, Special Interest Group on Computer Personnel Research Annual Conference. Session, 3.2, 147-149.

Leonard-Barton, D. (1992). Core capabilities and core rigidities: A paradox in managing new product development. Strategic Management Journal, 13, 111-125.

Marr, B. (2004). Management Consulting Practices on intellectual capital : Editorial and introduction to special issue. Journal of intellectual capital, 6(4), 493-496.

Mowday, R. T., Steers, R. M. \& Porter, L. W. (1979). The Measurement of Organizational Commitment. Journal of Vocational Behavior, 14, 224-247.

Nishii, L.H., Lepak, D.P. \& Schneider, B. (2008). Employee attributions of the "why" of HR practices: Their effects on employee attitudes and behaviors, and customer satisfaction. Personnel Psychology, 61(3), 503-45.

OECD, (1996). Measuring what people know: Human capital accounting for the knowledge economy, Paris : OECD.

Omar, F., Halim, F. W., Zainah, A. Z., Farhadi, H., Nasir, R., \& Khairudin, R. (2011). Stress and Job Satisfaction as Antecedents of Workplace Deviant Behavior. World Applied Science Journal, 12, 46-51, ISSN 1818-4952.

Peltoniemi, M. \& Vuori, E. (2005). Competitive intelligence and co-evaluation within an organization population. Proceedings of the 6th European Conference on Knowledge Management, September 8-9. Limerick, Ireland.

Ployhart, R. E. \& Vandenberg, R. J. (2010). Longitudinal research: The theory, design, and analysis of change. Journal of Management, 36 (1), 94-120. 
Reed, K.K., Lubatkin, M. and Srinivasan, N. (2006). Proposing and testing an intellectual capital-based view of the firm. Journal of Management Studies, 43(4), 867-893.

Sanchez, R., Heene, A., \& Thomas, H. (1996). Introduction: Towards the Theory and Practice of Competence-Based Competition B2 - Introduction: Towards the Theory and Practice of Competence-Based Competition. Oxford: Pergamon Press.

Senyucel, Z. (2012). Managing Human Resources in the 21st Century. Available at http://www.bookboon.com; Accessed on 01/12/2019.

Slemp, G. R. \& Vella-Brodrick, D. A. (2013). Slemp, G. R., \& Vella-Brodrick, D. A., (2013). The job crafting questionnaire: A new scale to measure the extent to which employees engage in job crafting. International Journal of Wellbeing, 3(2), 126-146. doi:10.5502/ijw.v3i2.1.

Stewart, T. A. (2007). Intellectual Capital : The wealth of new organizations. Nicholas barely publishing.

Takeuchi, R., Lepak, D.P., Wang, H. \& Takeuchi, K. (2007). An empirical examination of the mechanisms mediating between high-performance work systems and the performance of Japanese organizations. Journal of Applied Psychology, 92(4), 1069-83.

Tekeuchi, R., Chen, G. \& Lepak, D.P. (2009). Through the looking glass of a social system: cross-level effects of high-performance work systems on employees' attitudes. Personnel Psychology, 62(1): 1-29.

White, M. \& Bryson, A. (2013). Positive employee attitudes: how much human resource management do you need? Human Relations, 66 (3), 385-406. ISSN: 0018-7267, DOI: $10.1177 / 0018726712465096$.

Yu, B. B. \& Egri, C. P. (2005). Human resource management practices and affective organizational commitment: A comparison of Chinese employees in a stateowned enterprise and a joint venture. Asia Pacific Journal of Human Resources, 43(3), 332-360. 